\title{
Picogram of Prostaglandin E2 per Milligram of Protein
}

National Cancer Institute

\section{Source}

National Cancer Institute. Picogram of Prostaglandin E2 per Milligram of Protein. NCI

Thesaurus. Code C67476.

A unit of mass fraction of Prostaglandin E2 expressed as number of picograms of Prostaglandin E2 per one milligram of total protein. 